\title{
Skeletal architecture of middle Cambrian spicular radiolarians revealed using micro-CT
}

\author{
Jiani Sheng ${ }^{1}$, Sarah Kachovich ${ }^{1,2}$, and Jonathan C. Aitchison ${ }^{1}$ \\ ${ }^{1}$ School of Earth and Environmental Sciences, The University of Queensland, St. Lucia, 4072, Australia \\ ${ }^{2}$ International Ocean Discovery Program, Texas A\&M University, TX, 77845, USA
}

Correspondence: Jiani Sheng (j.sheng@uq.edu.au)

Received: 14 August 2019 - Revised: 17 April 2020 - Accepted: 22 April 2020 - Published: 26 May 2020

\begin{abstract}
X-ray micro-computed tomography (micro-CT) is used to resolve the detailed internal architecture of the siliceous skeletons of two well-preserved middle Cambrian (Miaolingian Series) radiolarians from the Inca Formation of the Georgina Basin, Australia. Digital dissections of specimens of Archeoentactinia incaensis and A. tetractinia reveal for the first time that both are exclusively composed of tetractine spicules. A basal layer consisting of robust spicules together with an interwoven meshwork of smaller spicules is observed in both micro-CT models. Detailed structural analysis with the aid of a digitally inserted artificial sphere shows that the framework spicules are likely to have been added one by one as the radiolarian cell enlarged. The timing of spicule genesis may be an important factor controlling the morphology of different groups of spicular radiolarians. Observation of these fundamental skeletal structures suggests that the type genus of Archeoentactiniidae Archeoentactinia belongs to Echidninidae; thus, Archeoentactiniidae is a junior synonym of Echidninidae.
\end{abstract}

1

\section{Introduction}

Radiolarian microfossils represent an important tool for biostratigraphy, palaeoceanography and evolutionary studies (De Wever et al., 2001; Lazarus, 2005; Aitchison et al., 2017). However, their potential in the Lower Paleozoic has not yet been fully realised due to an underdeveloped understanding of their taxonomy. This relates to our presently limited understanding of their skeletal structures, which are dominated by complex spicular and multispherical forms (Won and Below, 1999; Maletz, 2011; Caridroit et al., 2017). This knowledge gap has impeded resolution of the taxonomic significance of different skeletal and structural elements. Over the last two decades, abundant, diverse and well-preserved assemblages have been recovered from middle Cambrian strata of the Georgina Basin, Australia, and upper Cambrian to Lower Ordovician strata from Newfoundland, Canada (Won and Below, 1999; Won and Iams, 2002; Won et al., 2005, 2007; Pouille et al., 2014). Although the radiolarians reported exhibit excellent preservation, structural descriptions of many groups remain vague and superficial due to the limitations of traditional imaging methods using scanning electron mi- croscopy (SEM) and transmitted light microscopy (TLM). The higher-level placement of numerous genera and even some families remains unresolved. Relationships amongst different groups are also poorly understood.

The earliest undisputed radiolarians are from Cambrian Series 2 (Geyer, 2019) of the Altai Mountains, Russia; however, the reported assemblages are of low diversity and poor preservation (Obut and Iwata, 2000; Pouille et al., 2011). The middle Cambrian Georgina Basin fauna includes the oldest well-preserved radiolarians with remarkable diversity (Bengtson, 1986; Won and Below, 1999; Maletz, 2011). Detailed understanding of the skeletal architecture of these fossils is crucial for the development of Lower Paleozoic taxonomy. Micro-computed tomography (micro$\mathrm{CT}$ ) gives an opportunity to achieve this goal by providing high-resolution computed tomographs, which can be reconstructed into three-dimensional models for thorough investigations (Kachovich et al., 2019; Kachovich and Aitchison, 2020; Perera et al., 2020). In this study, we revisited localities reported by Won and Below (1999) and collected 18 limestone concretion samples from the Inca Formation. Radiolarians are extremely rare but micro-CT analyses of spec- 
imens of Archeoentactinia incaensis and A. tetractinia reveal previously unrecognised structures based purely on tetractine spicule construction.

\section{Geological setting}

The Georgina Basin is part of the epicontinental Centralia Basin, covering an area around $325000 \mathrm{~km}^{2}$ (Smith, 1972; Fig. 1a). It contains sedimentary and volcanic rocks of Neoproterozoic to Devonian age and is dominated by Cambrian marine sediments (Smith, 1972; Southgate and Shergold, 1991; Dunster et al., 2007). Our study material comes from the Inca Formation, which crops out near Camooweal and Duchess areas (Smith, 1972). The Inca Formation was deposited in a shelfal marine, organic-rich environment and is dominated by organic-rich siliceous shale, biogenic chert, siltstone and limestone (Smith, 1972). It preserves a diverse assemblage of fossils, including trilobites, archaeocopides, linguliformean brachiopods, hyoliths, molluscs, sponge spicules and radiolarians (Öpik, 1970, 1979; Fleming, 1973; Jell, 1975; Bengtson, 1986; Shergold and Southgate, 1986; Southgate and Shergold, 1991; Won and Below, 1999). The age of the Inca Formation is constrained by the occurrence of trilobites of the Wuliuan and Drumian stages of the Miaolingian Series (Ptychagnostus gibbus and Ptychagnostus punctuosus zones indicative of the Australian Templetonian and Undillan stages, respectively: Öpik, 1979; Shergold et al., 1985; Shergold, 1995; Shergold and Cooper, 2005; Babcock et al., 2007; Peng et al., 2009; Ogg et al., 2016; Zhao et al., 2019; Geyer, 2019).

At the Thorntonia locality, the near flat-lying Inca Formation disconformably overlies the Beetle Creek Formation and has a thickness of around 3-60 m (Smith, 1972; Won and Below, 1999). It has limited exposures in creek banks in a low relief landscape (Öpik and Pritchard, 1960; Smith, 1972). A total of 16 samples from limestone concretions, weathered out from the bedrock, were collected from a dry creek bed at horizontal intervals of $50 \mathrm{~m}$ along a N-S-trending $800 \mathrm{~m}$ long traverse (from $19^{\circ} 44^{\prime} 15.7^{\prime \prime} \mathrm{S}, 138^{\circ} 53^{\prime} 51.9^{\prime \prime} \mathrm{E}$ to $19^{\circ} 43^{\prime} 57.6^{\prime \prime} \mathrm{S}, 138^{\circ} 53^{\prime} 47.7^{\prime \prime} \mathrm{E}$; WGS84; Fig. 1b). Each of the samples includes four to six concretion fragments weighing around $20 \mathrm{~kg}$ in total. Abundant sponge spicules exposed by natural weathering could be observed on all sample surfaces with the naked eye. Only one sample (SEES/TH12) yielded radiolarians.

At the Rogers Ridge locality, the Inca Formation has a thickness around $150 \mathrm{~m}$ and also disconformably overlies the Beetle Creek Formation. Two limestone concretion samples, weathered out from the bedrock, were collected on a gently sloped hill, $7 \mathrm{~km}$ east of the Monument Village (a village associated with Phosphate Hill mine) $\left(21^{\circ} 45^{\prime} 08.6^{\prime \prime} \mathrm{S}, 139^{\circ} 59^{\prime} 00.2^{\prime \prime} \mathrm{E}\right.$; WGS84; Fig. 1c). Only one sample (SEES/RR1) yielded rare radiolarians and some globular siliceous microfossils of unknown affinity.

\section{Materials and methods}

Limestone concretions were broken up into $5 \mathrm{~cm}^{3}$ fragments and digested using $5 \%$ acetic acid. Residues were wet sieved once every 2 weeks for several months. Materials between 63 and $500 \mu \mathrm{m}$ were collected and air dried. Although numerous sponge spicules were recovered radiolarians are extremely rare. An initial SEM examination was conducted using a Hitachi TM3030 desktop SEM at the School of Earth and Environmental Sciences of the University of Queensland.

Micro-CT imagery of two specimens of Archeoentactinia was captured using the Xradia Versa 500 scanner, at the Julius Kruttschnitt Mineral Research Centre of the University of Queensland. Sample preparation followed the method developed by Kachovich et al. (2019) for radiolarian micro-CT imagery. A mount was carved using a piece of acrylonitrile butadiene styrene (ABS) plastic, which is commonly used in additive manufacturing. A thin layer of ultraviolet curing resin, Norland Optical Adhesive 61, was applied to the mount as adhesive. Two specimens were carefully transferred onto the mount, which was cured under ultraviolet light.

The specimens were scanned for $4 \mathrm{~h}$ each with the current of the X-ray source set at $77 \mu \mathrm{A}$ and a beam voltage of $50 \mathrm{kV}$. A stack of 970 images with $0.7 \mu \mathrm{m}$ voxel size was reconstructed for each specimen. The acquired 3-D data set was processed with volume reconstruction software built in the Xradia 500 scanner and exported as 32-bit stacks. These were saved as greyscale TIFF images, which were then imported into Avizo ${ }^{\circledR} 9.5$ software for 3-D visualisation and data analysis. The specimens were separated from the glue in the "segmentation workroom" using density contrast. The cleaned models were manually dissected into individual spicules after careful observation. The spicules were each assigned a colour according to their sizes using the colour scheme developed by Kachovich et al. (2019). To better visualise and analyse the distribution of the framework spicules, the central points of each spicule were digitally isolated by manually removing their rays. To measure the distance of the spicule central points from the centre of the skeletal cavity, stereolithographic (STL) data for a sphere were imported and placed inside the internal cavity of the specimen. The sphere's size and position were adjusted to be in contact with the central points of the largest spicules. The distances between the central points and the surface of the artificial sphere were measured to test the sphericity of the framework. To enable better appreciation of the morphologies of the specimens in $3-\mathrm{D}$, two videos of the rotating specimens and their microCT models are available as supplemental data (Sheng et al., 2020).

\section{Discussion}

With the aid of micro-CT technology, we recognise that specimens of both Archeoentactinia incaensis and A. tetractinia are exclusively constructed from tetractine spicules that are 


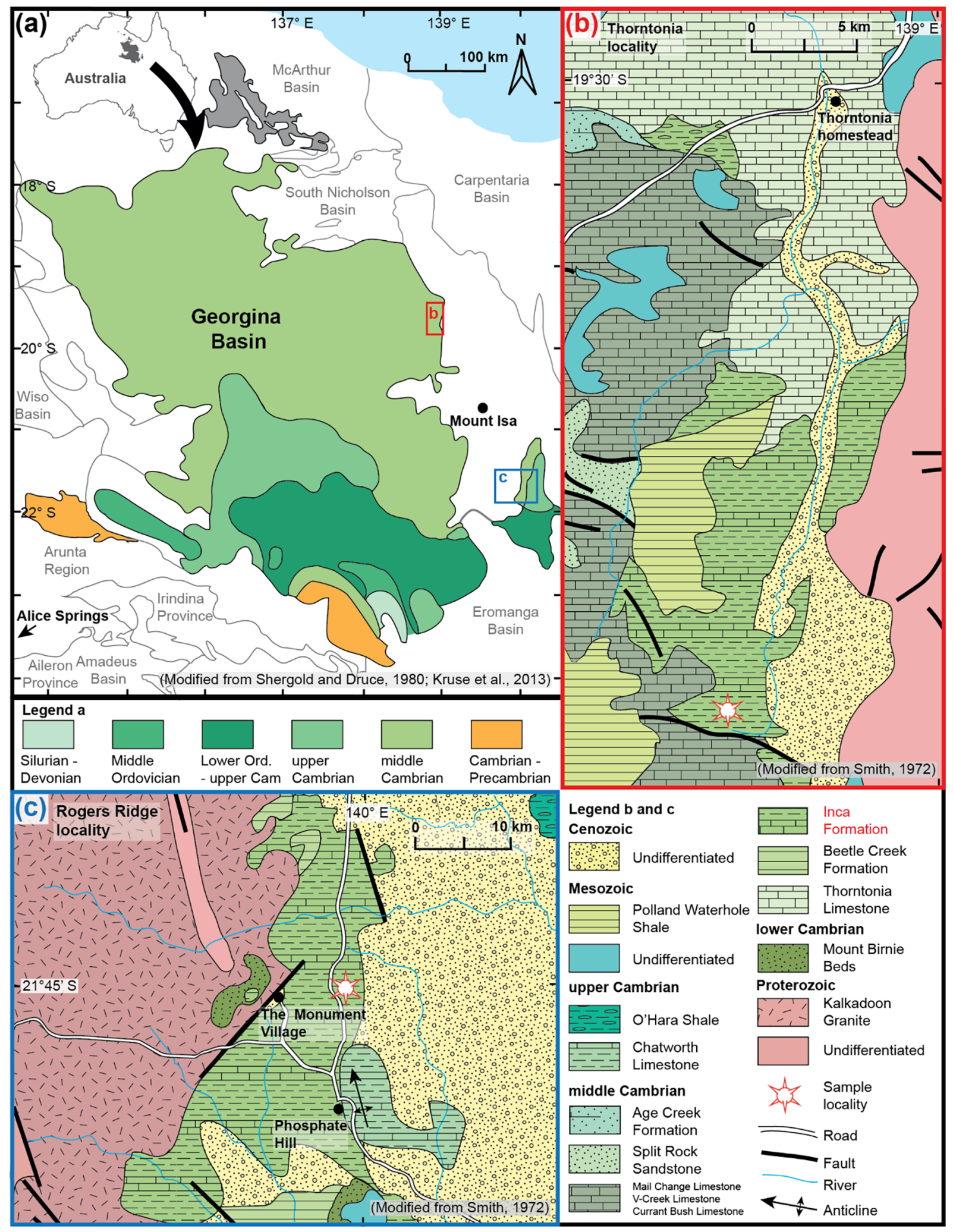

Figure 1. Maps showing sample locations in the radiolarian-bearing Inca Formation in the Georgina Basin, northern Queensland, Australia. (a) Position of the Thorntonia (Fig. 1b) and Rogers Ridge localities (Fig. 1c). Insert map in the top left-hand corner shows the extent of the Georgina Basin in relation to Australia (modified from Shergold and Druce, 1980; Kruse et al., 2013). (b) Geological map of the Inca Formation and sampling site (from $19^{\circ} 44^{\prime} 15.7^{\prime \prime} \mathrm{S}, 138^{\circ} 53^{\prime} 51.9^{\prime \prime} \mathrm{E}$ to $19^{\circ} 43^{\prime} 57.6^{\prime \prime} \mathrm{S}, 138^{\circ} 53^{\prime} 47.7^{\prime \prime} \mathrm{E}$; WGS84) at the Thorntonia locality (modified from Smith, 1972). (c) Geological map of the Inca Formation and sampling site $\left(21^{\circ} 45^{\prime} 08.6^{\prime \prime} \mathrm{S}, 139^{\circ} 59^{\prime} 00.2^{\prime \prime} \mathrm{E}\right.$; WGS84) at the Rogers Ridge locality (modified from Smith, 1972). 
both modified and fused (Figs. 2a-d; 3a-d). A basal framework constructed from robust spicules (Figs. 2e; 3e) and an interwoven meshwork built upon it constructed from smaller spicules form a three-dimensional-walled shell with numerous spines of various lengths and thicknesses. In comparison, the original diagnoses of the family Archeoentactiniidae and its type genus Archeoentactinia based on observations using SEM and TLM imagery suggested the presence of a spherical to subspherical test formed by a disorderly interwoven meshwork accompanied by one or more spicules (Won and Below, 1999). With traditional imaging methods such as SEM and TLM, the meshwork spicules are difficult to identify as they have various orientations and rays of different lengths. As the basal (innermost) framework layer is obscured by the meshwork, only a very limited and variable number of the largest spicules that are not covered are recognisable, depending on the orientation of the specimen during imaging (Won and Below, 1999; this study). The results of micro-CT analysis of specimens of $A$. incaensis and A. tetractinia demonstrate the effectiveness of this methodology in understanding radiolarians with complex spicular structures.

Using micro-CT to determine the exclusively spicular composition of Archeoentactinia specimens from the Inca Formation reveals that the type genus of the Archeoentactiniidae belongs to the Echidninidae; therefore, Archeoentactiniidae is a junior synonym of Echidninidae. Five other genera, Pararcheoentactinia, Spongomassa, Fungomacula, Lithosphaera and Sphaeroentactinia, which were originally placed within Archeoentactiniidae, should also be investigated using micro-CT (Won and Below, 1999; Noble et al., 2017). As with Archeoentactinia, understanding the nature of their meshwork structures will aid appropriate higher-level taxonomic placement and provide a better understanding of the skeletal evolution of early radiolarians.

The order Archaeospicularia was erected to bring together spicule-constructed Paleozoic radiolarians based on observations from upper Cambrian and Lower Ordovician assemblages from Australia and Canada (Nazarov and Ormiston, 1984; Bengtson, 1986; Noble, 1994; Kozur et al., 1996; Dumitrica et al., 2000). Radiolarians with an exclusively spicular composition were considered to be ancestral forms that gave rise to diverse later forms without or with only minor spicular components, which dominate the fossil record from the Middle Paleozoic onwards (Kozur et al., 1996; Dumitrica et al., 2000; De Wever et al., 2001). However, SEM and TLM images of middle Cambrian specimens appeared to challenge the ancestral position of Archaeospicularia and the view that spicules are the fundamental skeletal elements of radiolarians (Won and Below, 1999). Three groups were described within the middle Cambrian fauna including the palaeospiculids, the parechidninids and the archeoentactiniids. The palaeospiculids consist of a single six-rayed spicule with subsidiary structures, while the other two were recognised to be meshwork dominated. This has resulted in a popular misconception that middle Cambrian faunas are dominated by radiolarians with three-dimensional-walled spherical shells constructed by a thread-like meshwork, while the purely spicule-constructed forms are subordinate. The archeoentactiniids make up $80 \%$ of the species described as being meshwork dominated (Won and Below, 1999). Recognition of the wholly spicular composition of Archeoentactinia suggests that middle Cambrian radiolarians may be dominated by forms constructed from highly modified spicules.

Sets of double and triple spicules revealed by micro-CT analysis also provide evidence of the ancestral position of the Archaeospicularia as they indicate a possible link between A. incaensis and the order Entactinaria (Fig. 2c). These sets of spicules resemble the characteristic bar-centred spicules of the order Entactinaria, which was first described from the upper Cambrian and dominates the radiolarian fossil record from the Ordovician to the Permian (Kozur and Mostler, 1982; Nazarov, 1975). The early evolution of this order is still poorly understood. Some authors have proposed that Entactinaria may have been derived from Archaeospicularia by reduction of numerous spicules to a single bar-centred one (Kozur et al., 1996; Dumitrica et al., 2000; De Wever et al., 2001). Maletz (2011) proposed that bar-centred spicules may have originated from additional development of whorled rays on a point-centred spicule in palaeospiculids. The discovery of sets of spicules in A. incaensis shows that at least one mechanism to form bar-centred spicules had already evolved in the Archaeospicularia by middle Cambrian time.

To test the hypothesis that spherical radiolarians with minor spicule elements could evolve from purely spiculeconstructed forms represented by the family Echidninidae, the recognition of transitional forms is crucial. Micro-CT results suggest that $A$. incaensis may represent one such form. This specimen has a basal layer and a meshwork that are partially interwoven and partially separate. A model of the framework, with the tangential spines removed, structurally resembles a latticed sphere with radial spines (Fig. 2h). There are some meshwork spicules and some outgrowths on several spines lie above and parallel to the basic framework (Fig. 2a, k). They may represent an early stage evolution of an outer sphere. Kozur et al. (1996) previously proposed that the Lower Ordovician (Tremadocian) species Parechidnina nevadensis represents one such transitional form. The original diagnosis of this genus is comparable to the structure of $A$. incaensis discussed herein, with $P$. nevadensis possessing spicules of more unified sizes. This proposition is regarded contentious as the spicular nature of $P$. nevadensis could not be determined based on SEM and TLM images. Different authors have placed the genus Parechidnina under Echidninidae (Kozur et al., 1996; Noble et al., 2017) and Aspiculidae (Won and Below, 1999; Won et al., 2005), despite contradictory diagnoses with the former defining a purely spicular composition and the latter strictly non-spicular. MicroCT examination of specimens of Parechidnina will not only resolve uncertainty surrounding family-level assignment but also provide data for detailed comparison between A. incaen- 

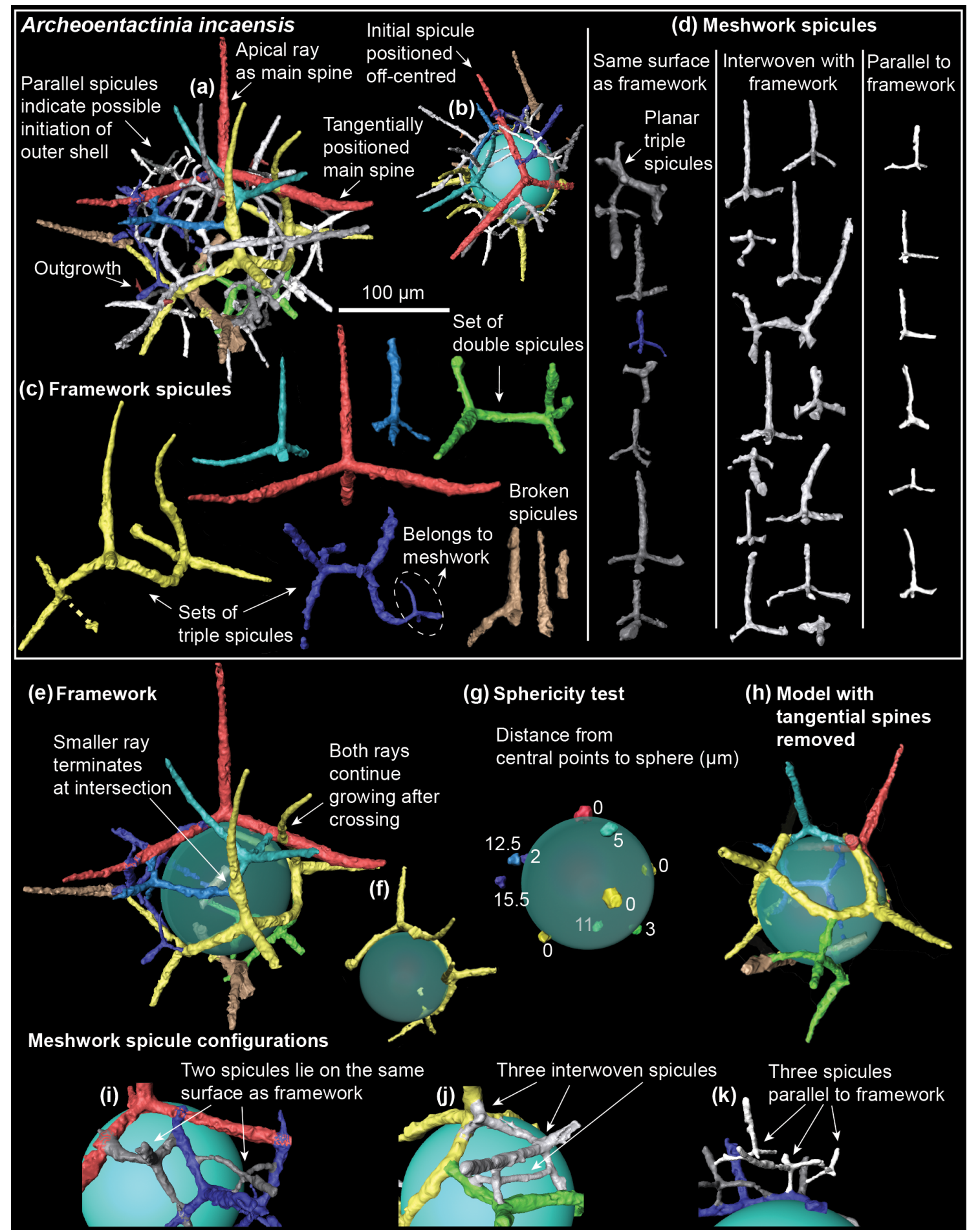

Figure 2. Micro-CT models of Archeoentactinia incaensis (SEES/TH12-AIN01) illustrating complete specimen, segmented spicules, framework and meshwork. An artificial pale green sphere is digitally inserted into the model to test the sphericity. (a) Micro-CT model of the complete specimen, with apical ray, tangential spine and parallel meshwork spicules annotated. (b) View from the top of the specimen showing off-centred initial spicule. (c) Individual spicules making up the basal framework. (d) Individual spicules making up the meshwork. (e) Micro-CT model of the basal framework; two fusing modes are indicated. (f) One set of triple spicules conforming well to the inserted digital sphere. (g) Distances from central points of framework spicules to spherical surface. (h) Micro-CT model of isolated framework with tangential spines removed. (i) Example of meshwork spicules that lie on the same surface as the framework. (j) Example of three interwoven meshwork spicules. (k) Example of three spicules that lie above and parallel to the framework. Images (i-k) are enlarged and partially displayed in order to zoom in to show the three types of configurations of the meshwork spicules. 
sis and $P$. nevadensis, which will clarify if any evolutionary lineage exists between these species and whether or not they represent successive transitional forms between spiculeconstructed and spherical radiolarians.

In addition to providing insight into higher-level taxonomy, micro-CT enables detailed structural analysis which provides data that can be used to better understand radiolarian skeletal growth modes. Relating structural characteristics to growth patterns can help identification of controlling factors behind various structures and thus contribute towards a fundamental understanding of the phylogenetic importance of each skeletal element. Skeletal growth models for radiolarians have been proposed since 1887 based on observations of individuals at different ontogenetic stages (Anderson and Bennett, 1985; Thurow and Anderson, 1986; Haeckel, 1887; Swanberg and Bjørklund, 1987; Suzuki, 2006; Itaki and Bjørklund, 2007; Kruglikova et al., 2009; Ogane et al., 2010). However, the exact nature of skeletal growth processes remains unknown due to the difficulty in culturing radiolarians in laboratory conditions (De Wever et al., 2001; Ogane et al., 2010). Based on some established biomineralisation mechanisms (Mann, 1997, 2000; Ehrlich et al., 2010) and radiolarian skeletogenesis theories, we can speculate on the growth patterns of the two Inca Formation specimens. The central points of the spicules are regarded as the sites of skeletal genesis (De Wever et al., 2001). Longitudinal growth of the rays is followed by thickening with episodic additional silica deposition on the surface (Nishimura, 1990; Ogane et al., 2009, 2010). Therefore, we speculate that in spherical spicular radiolarians the timing of spicule growth initiation should be reflected in spicule size and their distance from the centre of the test. To test this hypothesis, we measured the distances between the central points of each framework spicule and the surface of an inserted digital sphere. To enable better visualisation of distances, the rays of each spicule are digitally removed with only the central points remaining (Figs. $2 \mathrm{~g} ; 3 \mathrm{~g}$ ). Amongst the individual spicules that do not share rays with other spicules, there is a negative correlation between the size and the distance. This suggests that the spicules may have been added one by one as the cells grew larger. We can therefore posit that the step-wise skeletal genesis resulted in the subsphericity of these radiolarians and the off-centred position of the initial spicule. On the other hand, the spherical tests of Echidnina, Subechidnina and Curvechidnina constructed from spicules that are more or less uniform in size may be a result of synchronous spicule genesis. Thus, the timing of the initiation of spicules may be one of the factors influencing the morphology of early radiolarians.

A. incaensis and A. tetractinia specimens differ by the presence of a remarkably large initial spicule in A. tetractinia (Figs. 2a; 3a; Won and Below, 1999). The hypothesis regarding spicule size and correlation with the timing of their development discussed above may enable us to assess whether this characteristic is better defined as an ontogenetic or interspecific difference. The extra-large size of the initial spicule may be regarded as a result of an extra-long pause between genesis of the initial spicule and that of the rest of the spicules. Since the timing of spicule genesis may have contributed to genus-level variations such as those between Archeoentactinia and Echidnina as discussed in the last paragraph, the authors consider the possibly timing related morphologic difference between A. incaensis and A. tetractinia should be regarded as interspecific variation.

Although micro-CT observation is extremely timeconsuming, the improved taxonomic understanding gleaned from high resolution analysis of two specimens demonstrates the great potential of this method for improving our understanding of the early evolutionary stages of this important group of planktonic microorganism. Digital dissection reduces the tests to their simplest elements and thus helps us to identify fundamental skeletal structures. Detailed structural analysis helps us to determine the elements that differentiate between groups at various taxonomic ranks, thus contributing towards standardised guidelines for detailed classification. Accurate measurements provide new data to guide speculation about skeletal growth, as well as means to test growth pattern hypotheses. Coupled with studies of living radiolarians, this will serve as an excellent tool for the development of a radiolarian classification scheme that is closest to their natural phylogeny.

\section{Systematic palaeontology}

Phylum Radiozoa Cavalier-Smith, 1987

Class Polycystina Ehrenberg, 1838, emend. Riedel, 1967

Order Archaeospicularia Dumitrica, Caridroit and De Wever, 2000

Family Echidninidae Kozur, Mostler and Repetski, 1996

Archeoentactiniidae Won, 1999, p. 331.

\section{Diagnosis}

"Isolated, but interlocked or fused, primary point-centred tetractine, pentactine, hexactine and heptactine spicules form a subglobular, loose, spongy, hollow shell." (Kozur et al., 1996)

\section{Remarks}

The diagnosis of Echidninidae was revised by Won and Iams (2002) with additional descriptions of the range of spicule and spicule ray numbers. The authors' preference is to follow the decision of Noble et al. (2017), in which 


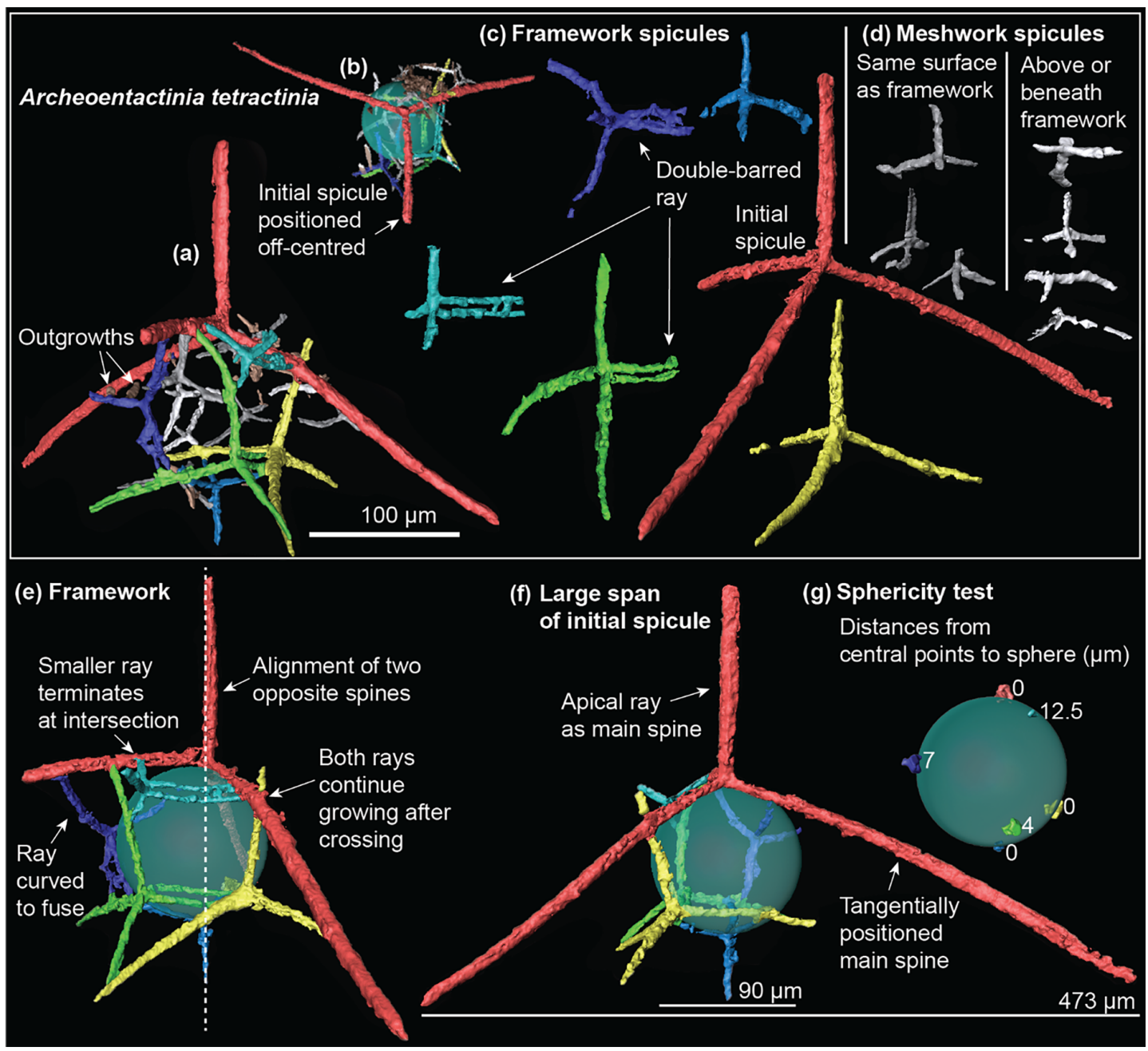

Figure 3. Micro-CT models of Archeoentactinia tetractinia (SEES/TH12-ATE01) illustrating the complete specimen, segmented spicules and basal framework. An artificial pale green sphere is inserted to test its sphericity. (a) Complete specimen with two outgrowths annotated. (b) View from the top of the specimen showing off-centred initial spicule. (c) Framework spicules, with double-barred rays annotated. (d) Meshwork spicules. (e) Framework showing angular configuration, with curved ray, alignment of opposite spines and two modes of rayfusing annotated. (f) Framework showing the large span of the initial spicule, with apical ray and tangential spines annotated. (g) Distances from central points of framework spicules to spherical surface.

the original diagnosis of Kozur et al. (1996), which adequately captures the family-level characteristics of Echidninidae, is kept. Detailed micro-CT examination suggests that the family Archeoentactiniidae is best regarded as a junior synonym of Echidninidae. In this study, both specimens (Figs. 2-3) investigated using micro-CT belong to the type genus of the family Archeoentactiniidae Archeoentactinia. The three-dimensional models reveal that their skeletons are constructed exclusively of spicules, consistent with the diagnosis of the family Echidninidae. A pure spicule composition can be identified in all the Archeoentactinia specimens (Fig. 4: 11-18) investigated using SEM in this study. The establishment of the family Archeoentactiniidae was based on some degree of misconception due to limitations of the SEM imagery. Micro-CT investigation is required to determine the skeletal structure and placement of other genera Pararcheoentactinia, Spongomassa, Fungomacula, Lithosphaera and Sphaeroentactinia originally assigned to Archeoentactiniidae (Won and Below, 1999; Won and Iams, 2002; Maletz and Bruton, 2007; Noble et al., 2017). In all five genera, the most robust initial spicule is obvious, while the nature of their meshwork is difficult to determine based on SEM imagery alone due to the optical density of their complex structures.

Genus Archeoentactinia Won, Won and Below, 1999

\section{Type species}

Archeoentactinia incaensis Won from limestone concretions of the Inca Formation, Georgina Basin, Australia (Won and Below, 1999). 


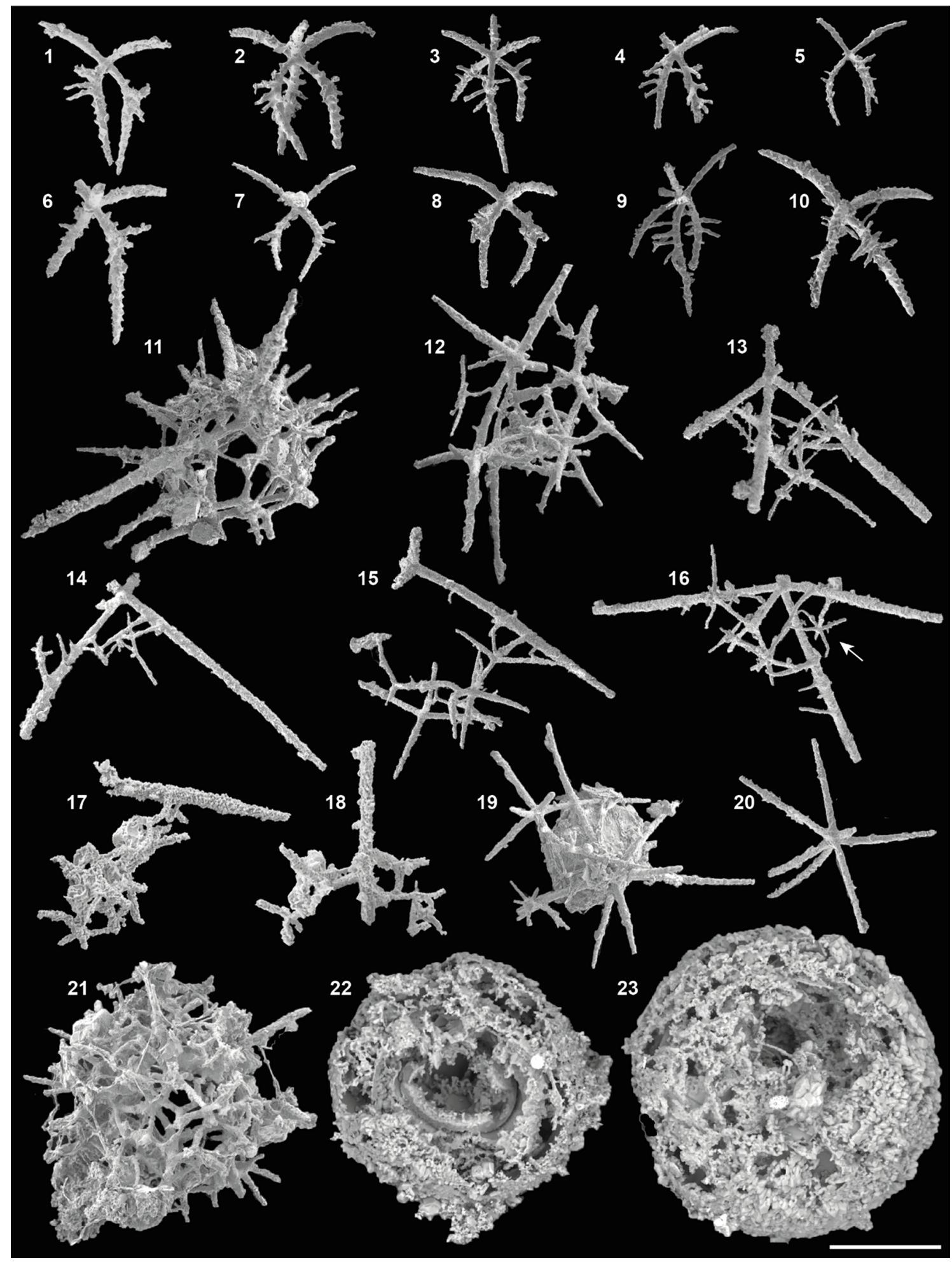

Figure 4. SEM images of radiolarians recovered from sample SEES/TH12 (1-16, 19-21) and SEES/RR1 (17-18, 22-23) from the Inca Formation, Georgina Basin, Australia. Scale bar: $100 \mu \mathrm{m}$ for 1-21, $50 \mu \mathrm{m}$ for 22-23. (1-10) Palaeospiculum arcussimile Won, SEES/TH12PAR01-SEES/TH12-PAR10. (11-12) Archeoentactinia incaensis Won, SEES/TH12-AIN02-SEES/TH12-AIN03. (13-14) Archeoentactinia hexactinia Won, SEES/TH12-AHE01-SEES/TH12-AHE02. (15-16) ?Archeoentactinia hexactinia Won, SEES/TH12-AHE03-SEES/TH12AHE04. (17-18) Archeoentactinia sp., SEES/RR1-ASP1-SEES/RR1-ASP2. (19-20) Echidnina irregularis Won, SEES/TH12-EIR01SEES/TH12-EIR02. (21) Parechidnina aspinosa Won, SEES/TH12-PAS01. (22-23) Fossils incertae sedis, imperfectly preserved siliceous microspheres of uncertain affinity, SEES/RR1-ISE01-SEES/RR1-ISEF02. 


\section{Revised diagnosis}

A hollow, subspherical test was constructed from an indefinite number of fused spicules with modified rays. Basal framework was constructed of a number of robust spicules of a range of sizes with a meshwork of smaller spicules arranged at various orientations formed upon it. The initial spicule is positioned off-centred and may be larger or significantly larger compared to others.

\section{Remarks}

In the original diagnosis, only one or two spicules are recognised with the rest of the test described as a disordered meshwork (Won and Below, 1999). Individual specimens of both Archeoentactinia incaensis and A. tetractinia were scanned using micro-CT and studied in detail. It is clear from appreciation of this new imaging technology that both specimens are exclusively constructed of tetractine spicules. In eight additional specimens of $A$. incaensis, A. hexactinia, ?A. hexactinia and $A$. sp. examined in this study by SEM, a purely spicular composition is all that can be observed (Fig. 4: 11-18). The genus Archeoentactinia needs further investigation to test the taxonomic significance of spicule raynumber variability within this group. It remains to be determined whether or not the number of rays affects the specieslevel classification (Won and Below, 1999). Representatives of A. angulata, A. delicata and A. hexactinia should also be investigated with micro-CT in order to determine species-level variations within this group (Won and Below, 1999). Archeoentactinia differs from other genera amongst the Echidninidae in the differentiation of spicules into the large basal framework-forming ones and small meshworkforming ones. Within the framework, there is also a range of spicule sizes with the initial spicule being the largest.

Archeoentactinia incaensis Won, Won and Below, 1999

Fig. 2; Fig. 4: 11-12.

1999 Archeoentactinia incaensis Won, Won and Below, pp. $333-334$, pl. 6 , figs. $1-9,16$, 17; pl. 8, figs. 16, 19; pl. 10, figs. 5-6.

\section{Revised diagnosis}

A hollow, subspherical test was constructed from an indefinite number of fused spicules with modified rays. Basal framework was constructed from a number of robust spicules with a meshwork formed upon it of smaller spicules arranged at various orientations. Amongst the framework spicules, there is a range of sizes, with the initial spicule being the largest and positioned off-centred.
Materials

Three specimens are identified from sample SEES/TH12 from the middle Cambrian (Miaolingian Series) Inca Formation at the Thorntonia locality, Georgina Basin, Australia.

\section{Description}

The subspherical test of the specimen of Archeoentactinia incaensis investigated using micro-CT is constructed out of 39 tetractine spicules of different sizes (test diameter $\varnothing$ : 138-170 $\mu \mathrm{m}$; Fig. 2a-d). Three additional broken spicules, on which original structures are not preserved, were also observed (Fig. 2c). The 39 spicules include 26 individual spicules and 13 that are joined with shared rays, forming five sets of triple and double tetractine spicules (Fig. 2c-d). The test has a basal framework constructed of large and robust spicules and a meshwork comprising smaller spicules with different orientations. The framework forms a complete and integral inner layer upon which the meshwork is built (Fig. 2e). Numerous spines and by-spines range from 30 to $130 \mu \mathrm{m}$ in length. All the intersection points between rays are fused with two different modes of fusing. In most cases, at the junction of two rays, the longitudinal growth of the smaller ray terminates when it encounters the larger ray (Fig. 2e). In two cases, the longitudinal growth of the smaller ray continues beyond the intersection point (Fig. 2e).

The framework contains 10 complete and three broken spicules (Fig. 2c). The 10 spicules are comprised of three individual spicules: one set of triple spicules (false coloured yellow), one set of double spicules (false coloured green) and two spicules belonging to a set of triple spicules (false coloured dark blue), where one spicule is considerably smaller and forms part of the meshwork (Fig. 2c). The initial spicule (false coloured red) is the only one on which all four rays are unmodified and is positioned closer to the side with the second and third most robust spicules (Fig. 2b). The set of triple spicules are the second, third and fourth largest and are joined in a line by two shared rays, which are curved and conform to the surface of a digitally inserted sphere (Fig. 2f). The set of double spicules (false coloured green) has a straight shared ray, with two spicules of similar size. The two individual spicules (false coloured aqua and light blue) have two and three rays involved in framework construction, respectively. There are two types of spines projecting from the test. Those associated with the apical rays of the spicules lie roughly concentric to the test. Those related to the basal rays lie tangential to the test and curve outwards (Fig. 2e).

The central points of the framework spicules are unevenly distributed and do not fall onto the same spherical surface. Their distances to the surface of the inserted sphere are up to $15.5 \mu \mathrm{m}$. The central points of the four largest spicules lie on the inserted spherical surface. The remaining six spicules lie $2-15.5 \mu \mathrm{m}$ above the spherical surface (Fig. $2 \mathrm{~g}$ ). There is a 
general trend where the distance between the central points and the digitally inserted sphere increases as the spicule size decreases. There is no such size and distance correlation for the spicules with shared rays.

The meshwork contains 29 spicules and a few fragments. There are 23 individual spicules, one set of double spicules, one set of triple spicules and one spicule belonging to a set of triple spicules, of which the other two spicules are considerably larger and form part of the framework. The set of double spicules is joined in a linear arrangement. The set of triple spicules differs from other sets by forming a more or less two-dimensional plane instead of a linear structure (Fig. 2d). The meshwork spicules fuse to the basal framework and to one another in three different configurations (Fig. 2i-k). Nine spicules (false coloured dark grey and dark blue) are formed on the same surface as the basal framework to which all three basal rays are attached and divide the large frames into smaller ones. A total of 14 spicules (false coloured light grey) have two basal rays attached to the basal framework, with the third one attached to the spines or rays of other meshwork spicules thus adding a spongy texture to the test. Six spicules (false coloured white) have three basal rays that lie above and parallel to the basal framework, by attaching one basal ray to a spine or attaching the apical ray to the framework. Four outgrowths can be observed on three by-spines (Fig. 2a).

\section{Occurrence}

Middle Cambrian (Miaolingian Series) of the Inca Formation from the Georgina Basin, Australia.

\section{Remarks}

The specimen of Archeoentactinia incaensis studied in detail as part of this investigation is exclusively constructed from fused and modified tetractine spicules, with a basal layer composed of robust spicules and a meshwork layer composed of smaller spicules. Its structure contrasts with the original species diagnosis, which indicates a meshwork constructed test with one or two spicules that are four or six rayed (Won and Below, 1999). The diagnosis of this species is thus revised herein. More study is required in order to investigate the importance of ray number variation within this group.

Archeoentactinia tetractinia Won, Won and Below, 1999

Fig. 3

1999 Archeoentactinia tetractinia Won, Won and Below, pp. 335-336, pl. 5, figs. 1-11.

\section{Revised diagnosis}

A hollow, subspherical test was constructed exclusively from fused tetractine spicules, with one remarkably large initial spicule positioned off-centred and forming a tent-like structure over the test. It contains a basal framework constructed from large spicules of a range of sizes and a meshwork formed upon it by small spicules arranged at various orientations.

\section{Materials}

One specimen identified from sample SEES/TH12 from the middle Cambrian (Miaolingian Series) Inca Formation at Thorntonia locality, Georgina Basin, Australia.

\section{Description}

The specimen investigated is composed of 13 tetractine spicules of different sizes, with a remarkably large initial spicule forming a tent-like structure over the subspherical test (test $\varnothing: 90 \mu \mathrm{m}$; Fig. 3a). The maximum span of the basal rays of the initial spicule reaches $473 \mu \mathrm{m}$ (Fig. 3f). It contains a framework constructed of large and robust spicules and a meshwork built upon it comprising small spicules (Fig. 3a). The framework forms a complete inner layer upon which the meshwork is built. Curved rays are present in both framework and meshwork spicules, where they curve towards other rays (Fig. 3a, e). All the intersection points between rays are fused, with two modes of fusing. In most cases, rays of smaller spicules terminate after intersecting and are fused to a ray associated with a larger spicule. In two cases, the smaller rays extend beyond the intersection point (Fig. 3e).

The framework contains six spicules. Three spicules that are the second, third and fourth largest contain one doublebarred basal ray, where there are two parallel rays close to one another initiating from the central point of the spicule (Fig. 3c). The initial spicule (false coloured red) is positioned to one side, towards the second and third most robust spicules (Fig. 3b). The four rays of the initial spicule serve as long spines, with the three basal rays forming a tentlike structure over the test (Fig. 3f). Apical and basal rays of the other five spicules form spines ranging 38 and $137 \mu \mathrm{m}$ in length. Central points of the six framework spicules are distributed unevenly and do not fall onto the same spherical surface. Central points of the two largest spicules and the sixth largest spicule, which is directly opposite to the initial spicule in the posterior position, lie on the surface of the inserted sphere. The other three lie above the spherical surface, with a negative correlation between the distance and their size (4-12.5 $\mu \mathrm{m}$; Fig. 3g).

Seven small spicules are added to the framework to make up the meshwork. Two types of meshwork construction are observed (Fig. 3d). Three spicules (false coloured dark grey) have their basal rays on the same spherical surface as the framework and four spicules (false coloured light grey) lie above or beneath the framework, which gives the test a spongy texture. No spicule was observed parallel to 
the framework. Two outgrowths are observed on one spine formed by a framework spicule.

\section{Occurrence}

Middle Cambrian (Miaolingian Series) of the Inca Formation from the Georgina Basin, Australia.

\section{Remarks}

Micro-CT investigation reveals the exclusive tetractine spicule composition of $A$. tetractinia; thus, its diagnosis is revised herein. The structure consists of a basal framework and a meshwork constructed from fused and modified spicules and conforms to the revised diagnosis of the genus Archeoentactinia (herein). At the species level, A. tetractinia distinctively differs from $A$. incaensis by possessing a remarkably large initial spicule. There are three other different features observed in the micro-CT models of the A. tetractinia and the A. incaensis specimens; however, it cannot be comprehensively determined at this stage whether they are variations within or across these two species. Double-barred spicules were observed in the A. tetractinia model but not in that of A. incaensis. Features observed in the model of $A$. incaensis that are absent in that of $A$. tetractinia include double and triple fused spicules sharing one or two rays, and meshwork spicules that are parallel to the basal framework.

Archeoentactinia hexactinia Won, Won and Below, 1999

Fig. 4: 13-14

1999 Archeoentactinia hexactinia Won, Won and Below, p. 333 , pl. 6, figs. 11-15, 18

\section{Materials}

Two specimens identified from sample SEES/TH12 from the middle Cambrian (Miaolingian Series) Inca Formation at the Thorntonia locality, Georgina Basin, Australia.

\section{Description}

A remarkably large initial spicule, which likely consists of six rays (initial spicule ray $L$ : $200-255 \mu \mathrm{m}$ ), and a purely spicular composition can be identified in both specimens. The long and robust basal rays of the initial spicules form a tent-like structure over the incompletely preserved tests (test $\varnothing$ of Fig. 4: 13: $100 \mu \mathrm{m})$.

\section{Occurrence}

Middle Cambrian (Miaolingian Series) of the Inca Formation from the Georgina Basin, Australia.

\section{Remarks}

Although the initial spicules of the specimens are incompletely preserved, they can be identified as six rayed through examination of the remnants of the broken rays, and can thus be assigned with some confidence to A. hexactinia. Within the genus Archeoentactinia, the taxonomic significance of spicule ray number is unclear. A. incaensis groups together specimens with four- to six-, and eight-rayed initial spicules. However, when the initial spicule is considerably larger than the other spicules, specimens with six-rayed and four-rayed initial spicules are differentiated into $A$. hexactinia and A. tetractinia (Won and Below, 1999). Further investigation is required in order to determine the taxonomic significance of spicule-size and ray-number variations. The unique spicule composition observed in A. hexactinia conforms to our revised diagnosis for Archeoentactinia. Due to incomplete preservation of the specimens, the diagnosis of $A$. hexactinia is not revised herein despite the recognition of its spicular composition.

?Archeoentactinia hexactinia Won, Won and Below, 1999

Fig. 4: 15-16

\section{Materials}

Two specimens identified from sample SEES/TH12 from the middle Cambrian (Miaolingian Series) Inca Formation at the Thorntonia locality, Georgina Basin, Australia.

\section{Description}

The two specimens observed both contain a remarkably large initial spicule that is incompletely preserved and possibly consist of six rays (initial spicule ray $L: 200-255 \mu \mathrm{m}$ ). A purely spicular composition can be identified in both specimens. A small six-rayed spicule can be clearly observed in one specimen (Fig. 4: 16).

\section{Occurrence}

Middle Cambrian (Miaolingian Series) of the Inca Formation from the Georgina Basin, Australia.

\section{Remarks}

The number of rays on the initial spicules of these two specimens cannot be determined but is possibly six. Therefore, they are tentatively assigned to Archeoentactinia hexactinia. The exclusively spicular composition observed in these two specimens conforms to our revised diagnosis of Archeoentactinia. 
Archeoentactinia sp.

Fig. 4: 17-18

\section{Materials}

Two specimens recovered from sample SEES/RR1 from the middle Cambrian (Miaolingian Series) Inca Formation, Rogers Ridge, Georgina Basin, Australia.

\section{Description}

The two specimens observed both contain a long ray (ray $L$ : $\sim 160 \mu \mathrm{m}$ ) which possibly belong to a large initial spicule and a number of small spicules (ray $L: 20-30 \mu \mathrm{m}$ ). A purely spicular composition can be identified in both specimens.

\section{Occurrence}

Middle Cambrian (Miaolingian Series) of the Inca Formation from the Georgina Basin, Australia.

\section{Remarks}

Composition of spicules of large and smaller sizes is evident, which conforms to the revised diagnosis of the genus Archeoentactinia. Partial preservation prevents species-level identification.

Genus Echidnina Bengtson, 1986, sensu Won and Iams, 2002

Echidnina irregularis Won and Iams, 2002

Fig. 4: 19-20

2002 Echidnina irregularis Won and Iams, p. 25, figs. 5.5-12

\section{Materials}

Two specimens recovered from sample SEES/TH12 from the middle Cambrian (Miaolingian Series) Inca Formation at the Thorntonia locality, Georgina Basin, Australia.

\section{Description}

One specimen (Fig. 4: 19) has a subspherical test formed by large interlocking spicules of similar size (test $\varnothing: \sim 100 \mu \mathrm{m}$ ). The spicules consist of possibly seven slender vertical and whorled rays (ray $L: 20-155 \mu \mathrm{m}$ ). One specimen (Fig. 4: 20) is preserved as an isolated spicule, with seven rays preserved (ray $L: 20-100 \mu \mathrm{m}$ ). The structure of vertical and whorled rays is more visible in this specimen.

\section{Occurrence}

Middle Cambrian (Miaolingian Series) of the Inca Formation from the Georgina Basin, Australia. Late Cambrian (Furongian Series) units in the Cow Head Group, Newfoundland, Canada.

\section{Remarks}

The recovery of Echidnina irregularis in this study extends the first appearance of this species from the late Cambrian (Furongian) to the middle Cambrian (Miaolingian) (Won and Iams, 2002). The earliest report of specimens of the genus Echidnina was recovered from the Georgina Basin and described by Bengtson (1986), who at the time was uncertain about the taxonomic assignment.

Genus Parechidnina Kozur, Mostler and Repetski, 1996, sensu Won, Iams and Reed, 2005

Parechidnina aspinosa Won, Won and Below, 1999

Fig. 4: 21

1999 Aitchisonellum aspinosus Won, Won and Below, p. 352, pl. 8, figs. 1-5; pl. 10, figs. 9-10

2002 Parechidnina aspinosa s. 1. Won, Won and Below; Won and Iams, p. 31, figs. 11.1, 11.2, 11.15, 11.16, 12.1

2005 Parechidnina aspinosa Morphotype 2 Won, Won and Below; Won, Iams and Reed, p. 443, fig. 6.2, 6.4, 6.8, 6.9?, 6.13 ?

\section{Materials}

One specimen recovered from sample SEES/TH12 from the middle Cambrian (Miaolingian Series) Inca Formation at Thorntonia locality, Georgina Basin, Australia.

\section{Description}

A spherical test with vaguely recognisable layered spicule composition (test $\varnothing: \sim 200 \mu \mathrm{m}$ ) was observed. The spicular elements are unified in size and thickness.

\section{Occurrence}

Middle Cambrian (Miaolingian Series) Inca Formation from the Georgina Basin, Australia. Late Cambrian (Furongian Series) and earliest Ordovician (Tremadocian Stage) units in the Cow Head Group, Newfoundland, Canada.

\section{Remarks}

The diagnosis and family-level assignment of this genus remain controversial. Different interpretations regard the test to be either spicule or meshwork constructed. The genus has been assigned by different researchers to both Echidninidae 
(Kozur et al., 1996; Noble et al., 2017) and Aspiculidae (Won et al., 2005).

Family Palaeospiculidae Won, Won and Below, 1999

Palaeospiculumidae Won, Won and Below 1999: 338 (nom. corr. Maletz, 2011: 130)

Genus Palaeospiculum Won, Won and Below, 1999

Palaeospiculum arcussimile Won, Won and Below, 1999

Fig. 4: 1-10

1999 Palaeospiculum arcussimile Won, Won and Below, $\mathrm{p}$. 340 , pl. 1, figs. $1-4,16,17$; pl. 2, fig. 1

\section{Materials}

Overall, 10 specimens were identified from sample SEES/TH12 from the middle Cambrian (Miaolingian Series) Inca Formation at the Thorntonia locality, Georgina Basin, Australia.

\section{Description}

A single six-rayed spicule with curved rays consisting of three short and smooth apical rays and three long basal rays with spinules.

\section{Occurrence}

Middle Cambrian (Miaolingian Series) of the Inca Formation from the Georgina Basin, Australia.

\section{Remarks}

Specimens of Palaeospiculum arcussimile are somewhat smaller than those described by Won and Below, 1999, from the same locality (apical ray $L: 50-100 \mu \mathrm{m}$, herein vs. 85$135 \mu \mathrm{m}$, Won and Below, 1999; basal ray $L: 80-150 \mu \mathrm{m}$, herein vs. 130-211 $\mu \mathrm{m}$, Won and Below, 1999). Palaeospiculum arcussimile is the most common species recovered from the Inca Formation in this study.

\section{Fossils incertae sedis}

Fig. 4: 22-23

\section{Materials}

Two specimens from sample SEES/RR1 from the middle Cambrian (Miaolingian Series) Inca Formation, Rogers Ridge $\left(21^{\circ} 45^{\prime} 08.6^{\prime \prime} \mathrm{S}, 139^{\circ} 59^{\prime} 00.2^{\prime \prime} \mathrm{E}\right.$; WGS84), Georgina Basin, Australia.

\section{Description}

Siliceous globular microfossils ( $\varnothing: 135 \mu \mathrm{m}$ and $120 \mu \mathrm{m})$ possessing two-dimensional walls. In one specimen (Fig. 4: 22), two tightly spaced internal spherical structures can be observed.

\section{Remarks}

The two specimens are left in open nomenclature due to their imperfect preservation. Recovery and investigation of better preserved specimens is required in order to determine whether these siliceous spherical microfossils may represent early radiolarians. The earliest definite fossil record of non-spicular spherical radiolarians with two-dimensional shell wall characteristic of Spumellaria is from the Early Ordovician (Maletz, 2007; Maletz and Bruton, 2007). Spherical microfossils with single or multiple perforated and latticed shells from the lower Cambrian have been reported and classified as Spumellaria by several authors (White, 1986; Braun et al., 2007; Cao et al., 2014; Chang et al., 2018; Ma et al., 2019; Zhang and Feng, 2019). However, their true nature and age assignment have been treated with some degree of scepticism (Danelian et al., 2017; Maletz, 2017). Singleshelled spherical microfossils (test $\varnothing: \sim 350 \mu \mathrm{m}$ ) with perforated walls, regarded as having a possible radiolarian affinity, were earlier described from the middle Cambrian of Utah, USA (White, 1986), Queensland, Australia (Bengtson, 1986) and the lower Cambrian of Hubei, China (Morris and Chen, 1990). They were assigned to the genus Blastulospongia, which was first described from the middle Cambrian of western New South Wales, Australia by Pickett and Jell (1983) and tentatively classified within the Porifera. However, the Blastulospongia specimens described by Pickett and Jell (1983) were notably larger (test $\varnothing: \sim 2 \mathrm{~mm}$ ). Whether specimens with such great size differences can belong to the same group needs further investigation. Two recent publications (Ma et al., 2019; Zhang and Feng, 2019) reported over 300 moderately to well-preserved siliceous spherical microfossils (test $\varnothing$ : $86-233 \mu \mathrm{m}$ ) with four morphotypes classified as radiolarians from the Shuijingtuo and the Niujiaohe formations (both Cambrian Series 2) in South China. In this study, after much sample processing and picking, very rare spherical siliceous specimens (test $\varnothing$ : 118 $137 \mu$, Fig. 4: 22-23) were recovered from the middle Cambrian Inca Formation at the Rogers Ridge locality. Although the preservation of these specimens is not sufficient for further analysis, we note they appear to be multispherical. The multi-sphericity is comparable to material described by $\mathrm{Ma}$ et al. (2019) and Zhang and Feng (2019). Unfortunately, the material from China was only scanned with a low-resolution micro-CT device and 3-D models were not provided. We suggest that for the time being these forms remain in open nomenclature until well-preserved materials can be examined with high-resolution micro-CT. 


\section{Conclusions}

Micro-CT results suggest that the genus Archeoentactinia is exclusively constructed from spicules and belongs to the family Echidninidae; thus, Archeoentactiniidae is a junior synonym of Echidninidae. Detailed structural analysis reveals that Archeoentactinia incaensis may represent a transitional form from the most primitive Archaeospicularia, where undifferentiated spicules coalesce to form a globular test, to spherical forms, such as Entactinaria with bar-centred spicules. Analysis with a digitally inserted sphere suggests that the framework spicules of both examined specimens are likely to have been added one by one during the cell enlargement. The timing of skeletal genesis may be an important factor influencing the morphology of early radiolarians.

To date, representatives of the genus Archeoentactinia are known only from middle Cambrian (Miaolingian Series) rocks of the Georgina Basin, Australia, and its range remains uncertain. An estimate of a possible range, shown as a solid line in fig. 1 of Aitchison et al. (2017), is speculative and perhaps best viewed as a dashed rather than solid line. However, recognition of Echidnina irregularis in the Inca Formation indicates that the range of the genus Echidnina extends at least as far back to the Miaolingian. With further investigations of Cambrian radiolarians, our knowledge of the ranges of different genera and evolutionary lineages will undoubtedly improve.

Data availability. All radiolarian specimens are deposited at the School of Earth and Environmental Sciences at the University of Queensland.

Video supplement. Video 1: rotating micro-CT model of the Archeoentactinia incaensis specimen from the Inca Formation, Georgina Basin. Video 2: rotating micro-CT model of the Archeoentactinia tetractinia specimen from the Inca Formation, Georgina Basin. File 1: micro-CT model file of the Archeoentactinia incaensis specimen from the Inca Formation, Georgina Basin. File 2: micro-CT model file of the Archeoentactinia tetractinia specimen from the Inca Formation, Georgina Basin. Data are available from the UQ eSpace data repository (https://doi.org/10.14264/89f20d4; Sheng et al., 2020).

Author contributions. JCA conceived of the research, secured grant funding, organised and participated in the fieldwork and revised the manuscript. JS undertook the fieldwork, extracted and imaged specimens, analysed data and wrote the initial draft of the manuscript. SK developed the imaging methodology, aided in the process of data analysis and provided feedback on the manuscript.

Competing interests. The authors declare that they have no conflict of interest.
Acknowledgements. We thank Cathy Evans at the University of Queensland Julius Kruttschnitt Mineral Research Centre for conducting micro-CT measurements of the radiolarian specimens. We also thank Linda Nothdurft at the University of Queensland School of Earth and Environmental Sciences for her assistance in sample collection in the Georgina Basin. We thank Lloyd and Wendy Hick of Thorntonia station for giving us access to the fossil locations. Constructive remarks by reviewers Jörg Maletz, Olga Obut and editor Taniel Danelian greatly improved the initial manuscript.

Financial support. This research has been supported by the Australian Research Council towards investigation of Early Paleozoic radiolarian evolution (grant no. ARC DP 1501013325 to Jonathan C. Aitchison).

Review statement. This paper was edited by Taniel Danelian and reviewed by Jörg Maletz and Olga Obut.

\section{References}

Aitchison, J. C., Suzuki, N., Caridroit, M., Danelian, T., and Noble, P. J.: Paleozoic radiolarian biostratigraphy, Geodiversitas, 39, 503-531, https://doi.org/10.5252/g2017n3a5, 2017.

Anderson, O. R. and Bennett, P.: A conceptual and quantitative analysis of skeletal morphogenesis in living species of solitary radiolaria: Euchitonia elegans and Spongaster tetras, Mar. Micropaleontol., 9, 441-454, https://doi.org/10.1016/03778398(85)90010-6, 1985.

Babcock, L. E., Robison, R. A., Rees, M. N., Peng, S., and Saltzman, M. R.: The Global boundary Stratotype Section and Point (GSSP) of the Drumian Stage (Cambrian) in the Drum Mountains, Utah, USA, Episodes, 30, 85-95, https://doi.org/10.18814/epiiugs/2007/v30i2/003, 2007.

Bengtson, S.: Siliceous microfossils from the Upper Cambrian of Queensland, Alcheringa, 10, 195-216, https://doi.org/10.1080/03115518608619155, 1986.

Braun, A., Chen, J., Waloszek, D., and Maas, A.: First early Cambrian Radiolaria, Geol. Soc. Spec. Publ., 286, 143-149, https://doi.org/10.1144/SP286.10, 2007.

Cao, W., Feng, Q., Feng, F., and Ling, W.: Radiolarian Kalimnasphaera from the Cambrian Shuijingtuo Formation in South China, Mar. Micropaleontol., 110, 3-7, https://doi.org/10.1016/j.marmicro.2013.06.005, 2014.

Caridroit, M., Danelian, T., O’Dogherty, L., Cuvelier, J. C., Aitchison, J. C., Pouille, L., Noble, P. J., Dumitrica, P., Suzuki, N., Kuwahara, K., Maletz, J., and Feng, Q. L.: An illustrated catalogue and revised classification of Paleozoic radiolarian genera, Geodiversitas, 39, 363-417, https://doi.org/10.5252/g2017n3a3, 2017.

Cavalier-Smith, T.: The origin of eukaryotic and archaebacterial cells, Ann. NY. Acad. Sci., 503, 17-54, https://doi.org/10.1111/j.1749-6632.1987.tb40596.x, 1987.

Chang, S., Feng, Q., and Zhang, L.: New Siliceous Microfossils from the Terreneuvian Yanjiahe Formation, South China: The Possible Earliest Radiolarian Fossil Record, J. Earth Sci.-China, 29, 912-919, https://doi.org/10.1007/s12583-017-0960-0, 2018. 
Danelian, T., Aitchison, J. C., Noble, P., Caridroit, M., Suzuki, N., and O'Dogherty, L.: Historical insights on nearly 130 years of research on Paleozoic radiolarians, Geodiversitas, 39, 351-362, https://doi.org/10.5252/g2017n3a2, 2017.

De Wever, P., Dumitrica, P., Caulet, J. P., Nigrini, C., and Caridroit, M. (Eds.): Radiolarians in the Sedimentary Record, Gordon and Breach, London, 533 pp., https://doi.org/10.1201/9781482283181, 2001.

Dumitrica, P., Caridroit, M., and De Wever, P.: Archaeospicularia, new Radiolarian order; a new step for the classification of the Lower Paleozoic Radiolaria, CR. Acad. Sci. IIA, 8, 563-569, https://doi.org/10.1016/S1251-8050(00)00168-3, 2000.

Dunster, J., Kruse, P., Duffett, M., and Ambrose, G.: Geology and resource potential of the southern Georgina Basin: GIS package and report, Northern Territory Geological Survey, Australia, 232 pp., 2007.

Ehrenberg, C. G.: Über die Bildung der Kreidefelsen und des Kreidemergels durch unsichtbare Organismen, Abhandlungen der königlichen preussichen Akademie der Wissenschaften zu Berlin, 59-147, 1838 (In German).

Ehrlich, H., Demadis, K. D., Pokrovsky, O. S., and Koutsoukos, P. G.: Modern views on desilicification: biosilica and abiotic silica dissolution in natural and artificial environments, Chem. Rev., 110, 4656-4689, https://doi.org/10.1021/cr900334y, 2010.

Fleming, P. J. G.: Bradoriids From the Xystridura Zone of the Georgina Basin, Queensland, Geological Survey of Queensland, Palaeontological Papers, 31, 1-9, 1973.

Geyer, G.: A comprehensive Cambrian correlation chart, Episodes, 42, 321-332, https://doi.org/10.18814/epiiugs/2019/019026, 2019.

Haeckel, E.: Report on the Radiolaria collected by HMS Challenger during the years 1873-1876, Report of the Voyage of HMS Challenger, Zoology, 18, 1-1803, 1887.

Itaki, T. and Björklund, K. R.: Conjoined radiolarian skeletons (Actinommidae) from the Japan Sea sediments, Micropaleontology, 53, 371-389, https://doi.org/10.2113/gsmicropal.53.5.371, 2007.

Jell, P. A.: Australian Middle Cambrian eodiscoids with a review of the superfamily, Palaeontogr. Abt. A, 150, 1-97, 1975.

Kachovich, S. and Aitchison, J. C.: Micro-CT study of Middle Ordovician Spumellaria (radiolarians) from western Newfoundland, Canada, J. Paleontol., 94, 417-435, https://doi.org/10.1017/jpa.2019.88, 2020.

Kachovich, S., Sheng, J., and Aitchison, J. C.: Adding a new dimension to investigations of early radiolarian evolution, Sci. Rep.-UK, 9, 6450, https://doi.org/10.1038/s41598-019-42771-0, 2019.

Kozur, H. W. and Mostler, H.: Entactinaria subordo nov., a new radiolarian suborder, Geol. Paläont. Mitt. Innsbruck., 11, 399-414, 1982.

Kozur, H. W., Mostler, H., and Repetski, J. E.: Well-preserved Tremadocian primitive Radiolaria from the Windfall Formation of the Antelope Range, Eureka County, Nevada, USA, Geol. Paläont. Mitt. Innsbruck., 21, 245-271, 1996.

Kruglikova, S. B., Björklund, K. R., Hammer, Ø., and Anderson, O. R.: Endemism and speciation in the polycystine radiolarian genus Actinomma in the Arctic Ocean: Description of two new species Actinomma georgii n. sp. and A. turidae n. sp., Mar. Micropaleontol., 72, 26-48, https://doi.org/10.1016/j.marmicro.2009.02.004, 2009.

Kruse, P. D., Dunster, J. N., and Munson, T. J.: Georgina Basin, complied by: Ahmad, M. and Munson, T. J., in: Geology and mineral resources of the Northern Territory, edited by: Munson, T. J., Johnston, K. J., and Fuller, M. H., Northern Territory Geol. Surv. Spec. Publ., 5, 1-56, 2013.

Lazarus, D. B.: A brief review of radiolarian research, Palaontol. Z., 79, 183-200, 2005.

Ma, Q., Feng, Q., Cao, W., Zhang, L., Ye, Y., and Gu, S.: Radiolarian fauna from the Chiungchussuan Shuijingtuo Formation (Cambrian Series 2) in Western Hubei Province, South China, Sci. China Earth Sci., 62, 1645-1658, https://doi.org/10.1007/s11430-018-9335-0, 2019.

Maletz, J.: The Early Ordovician Beothuka terranova (Radiolaria) faunal assemblage in western Newfoundland, Palaontol. Z., 81 , 71-82, https://doi.org/10.1007/BF02988380, 2007.

Maletz, J.: Radiolarian skeletal structures and biostratigraphy in the early Palaeozoic (Cambrian-Ordovician), Palaeoworld, 20, 116133, https://doi.org/10.1016/j.palwor.2010.12.007, 2011.

Maletz, J.: The identification of putative Lower Cambrian Radiolaria, Rev. Micropaleont., 60, 233-240, https://doi.org/10.1016/j.revmic.2017.04.001, 2017.

Maletz, J. and Bruton, D. L.: Lower Ordovician (Chewtonian to Castlemainian) radiolarians of Spitsbergen, J. Syst. Palaeontol., 5, 245-288, https://doi.org/10.1017/S1477201907002039, 2007.

Mann, S.: Biomineralization: the form (id) able part of bioinorganic chemistry!, J. Chem. Soc. Dalton, 21, 3953-3962, https://doi.org/10.1039/A704004K, 1997.

Mann, S.: The chemistry of form, Angew. Chem. Int. Edit., 39, 3392-3406, 2000.

Morris, S. C. and Chen, M.: Blastulospongia polytreta n. sp., an enigmatic organism from the Lower Cambrian of Hubei, China, J. Paleontol., 64, 26-30, https://doi.org/10.1017/S0022336000042207, 1990.

Nazarov, B. B.: Radiolaria of the lower-middle Paleozoic of Kazakhstan, Trudy Akademiia Nauk SSSR, Trans Acad, Sci-USSR, Geol. Inst., 275, 1-203, 1975 (in Russian).

Nazarov, B. B. and Ormiston, A.: Tentative system of Paleozoic Radiolaria, in: Morphology, Ecology and Evolution of Radiolarians, edited by: Petrushevskaya M. G. and Stepanjants, S. D., Academiya Nauk SSSR, Zoological Institute, Leningrad, USSR, 64-87, 1984 (in Russian).

Nishimura, H.: Taxonomic study on Cenozoic Nassellaria (Radiolaria), Sci. Rep. Inst. Geosci. Univ. Tsukuba, Sec. B, Geol. Sci., 11, 69-172, https://doi.org/10.11501/3071870, 1990.

Noble, P. J.: Silurian radiolarian zonation for the Caballos Novaculite, Marathon Uplift, west Texas, B. Am. Paleont., 106, 5-55, 1994.

Noble, P. J., Aitchison, J. C., Danelian, T., Dumitrica, P., Maletz, J., Suzuki, N., Cuvelier, J., Caridroit, M., and O'Dogherty, L.: Taxonomy of Paleozoic radiolarian genera, Geodiversitas, 39, 419502, https://doi.org/10.5252/g2017n3a4, 2017.

Obut, O. T. and Iwata, K.: Lower Cambrian Radiolaria from the Gorny Altai (southern West Siberia), Novosti Paleontologii i Stratigrafii, 2-3, 33-37, 2000.

Ogane, K., Tuji, A., Suzuki, N., Kurihara, T., and Matsuoka, A.: First application of PDMPO to examine silicification 
in polycystine Radiolaria, Plankton Benthos Res., 4, 89-94, https://doi.org/10.3800/pbr.4.89, 2009.

Ogane, K., Tuji, A., Suzuki, N., Matsuoka, A., Kurihara, T., and Hori, R. S.: Direct observation of the skeletal growth patterns of polycystine radiolarians using a fluorescent marker, Mar. Micropaleontol., 77, 137-144, https://doi.org/10.1016/j.marmicro.2010.08.005, 2010.

Ogg, J. G., Ogg, G., and Gradstein, F. M.: Cambrian, in: A concise geologic time scale, edited by: Ogg, J. G., Ogg, G., and Gradstein, F. M , Elsevier, 41-55, https://doi.org/10.1016/B9780-444-59467-9.00005-4, 2016.

Öpik, A. A.: Redlichia of the Ordian (Cambrian) of northern Australia and New South Wales, Bureau of Mineral Resources, Geol. Geophys. Bull., 114, 66 pp., 1970.

Öpik, A. A.: Middle Cambrian agnostids: systematics and biostratigraphy, BMR, Geol. Geophys. Bull., 172, 188 pp., 1979.

Öpik, A. A. and Pritchard, P. W.: III Cambrian and Ordovician, J. Geol. Soc. Aust, 7, 89-114, 1960.

Peng, S., Babcock, L. E., Zuo, J., Lin, H., Zhu, X., Yang, X., Robison, R. A., Qi, Y., and Bagnoli, G.: The global boundary stratotype section and point (GSSP) of the Guzhangian Stage (Cambrian) in the Wuling Mountains, northwestern Hunan, China, Episodes, 32, 41-55, https://doi.org/10.18814/epiiugs/2009/v32i1/006, 2009.

Perera, S., Aitchison, J. C., and Nothdurft, L.: Middle Ordovician (Darriwilian) radiolarians from the Crawford Group, Scotland, Geol. Mag., https://doi.org/10.1017/S001675682000028X, online first, 2020.

Pickett, J. W. and Jell, P. A.: Middle Cambrian Sphinctozoa (Porifera) from New South Wales, Mem. Ass. Aust. Palaeont., 1, 85-92, 1983.

Pouille, L., Danelian, T., and Maletz, J.: Radiolarian diversity changes during the Late Cambrian-Early Ordovician transition as recorded in the Cow Head Group of Newfoundland (Canada), Mar. Micropaleontol., 110, 25-41, https://doi.org/10.1016/j.marmicro.2013.05.002, 2014.

Pouille, L., Obut, O. T., Danelian T., and Sennikov, N.: Lower Cambrian (Botomian) polycystine Radiolaria from the Altai Mountains (southern Siberia, Russia), edited by: Palevol, C. R., 10, 627-633, https://doi.org/10.1016/j.crpv.2011.05.004, 2011.

Riedel, W. R.: Some new families of Radiolaria, Proc. Geol. Soc. Lond., 1640, 148-149, 1967.

Sheng, J., Kachovich, S., and Aitchison, J. C.: Micro-CT 3D models and videos of two middle Cambrian spicular radiolarians recovered from the Georgina Basin, Australia, UQ eSpace, https://doi.org/10.14264/89f20d4, 2020.

Shergold, J. H.: Timescales 1. Cambrian. Australian Phanerozoic timescales, biostratigraphic charts and explanatory notes, Second series, AGSO (Record 1995/30), 1-32, 1995.

Shergold, J. H. and Cooper, R.: The Cambrian Period, in: A Geologic Time Scale, edited by: Gradstein, F., Ogg, J. G., and Smith, A., Cambridge, Cambridge University Press, 147-164, https://doi.org/10.1017/CBO9780511536045.012, 2005.

Shergold, J. H. and Druce, E. C.: Upper Proterozoic and Lower Palaeozoic rocks of the Georgina Basin, in: The geology and geophysics of northeastern Australia, edited by: Henderson, R. A. and Stephenson, P. J., Geol. Soc. Aust., Qld. Div., Australia, 149-174, 1980.
Shergold, J. H. and Southgate, P. N. (Eds.): Middle Cambrian phosphatic and calcareous lithofacies along the eastern margin of the Georgina Basin, western Queensland, Geol. Soc. Aust., Sydney, 89 pp., 1986.

Shergold, J. H., Jago, J. B., Cooper, R. A., and Laurie, J. R.: The Cambrian system in Australia, Antarctica and New Zealand, edited by: Shergold, J. H. and Palmer, A. R., IUGS, Publ. 19, 85 pp., 1985.

Smith, K. G.: Stratigraphy of the Georgina Basin, BMR, Geol. Geophys. Bull., 111, 156 pp., 1972.

Southgate, P. N. and Shergold, J. H.: Application of sequence stratigraphic concepts to Middle Cambrian phosphogenesis, Georgina Basin, Australia, J. Aust. Geol. Geophys., 12, 119-144, 1991.

Suzuki, N.: Ontogenetic growth and variation in the skeletal structure of two Late Neogene Sphaeropyle species (Polycystina radiolarians), J. Paleontol., $\quad 80, \quad 849-866, \quad$ https://doi.org/10.1666/00223360(2006)80[849:OGAVIT]2.0.CO;2, 2006.

Swanberg, N. R. and Björklund, K. R.: The pre-cephalic development of the skeleton of Amphimelissa setosa (Actinopoda: Nassellarida), Mar. Micropaleontol., 11, 333341, https://doi.org/10.1016/0377-8398(87)90005-3, 1987.

Thurow, J. and Anderson, O. R.: An interpretation of skeletal growth patterns of some Middle Cretaceous and modern radiolarians, Micropaleontology, 32, 289-302, https://doi.org/10.2307/1485723, 1986.

White, R. D.: Cambrian radiolaria from Utah, J. Paleontol., 60, 778780, https://doi.org/10.1017/S0022336000022307, 1986.

Won, M. and Below, R.: Cambrian Radiolaria from the Georgina Basin, Queensland, Australia, Micropaleontology, 45, 325-363, https://doi.org/10.2307/1486119, 1999.

Won, M. and Iams, W. J.: Late Cambrian radiolarian faunas and biostratigraphy of the Cow Head Group, western Newfoundland, J. Paleontol., 76, 1-33, https://doi.org/10.1017/S0022336000017315, 2002.

Won, M., Iams, W. J., and Reed, K. M.: Earliest Ordovician (early to middle Tremadocian) radiolarian faunas of the Cow Head Group, western Newfoundland, J. Paleontol., 79, 433-459, 2005.

Won, M., Iams, W. J., and Reed, K. M.: Late Tremadocian radiolarian faunas and biostratigraphy of the Cow Head Group, western Newfoundland, Canada, J. Korean Earth Sci. Soc., 28, 497-540, 2007.

Zhang, K. and Feng, Q. L.: Early Cambrian radiolarians and sponge spicules from the Niujiaohe Formation in South China, Palaeoworld, 28, 234-242, https://doi.org/10.1016/j.palwor.2019.04.001, 2019.

Zhao, Y., Yuan, J., Babcock, L. E., Guo, Q., Peng, J., Yin, L., Yang, X., Peng, S., Wang, C., Gaines, R., Esteve, J., Tai, T., Yang, R., Wang, Y., Sun, H., and Yang, Y.: Global Standard Stratotype-Section and Point (GSSP) for the conterminous base of the Miaolingian Series and Wuliuan Stage (Cambrian) at Balang, Jianhe, Guizhou, China, Episodes, 42, 165-183, https://doi.org/10.18814/epiiugs/2019/019013, 2019. 